\title{
Resistance of fly ash geopolymer binders to organic acids
}

\author{
Timothy A. Aiken · Jacek Kwasny $\cdot$ Wei Sha
}

Received: 25 April 2020/Accepted: 12 August 2020/Published online: 20 August 2020

(C) The Author(s) 2020

\begin{abstract}
Fly ash geopolymers are a relatively new class of binders with the potential to reduce the $\mathrm{CO}_{2}$ emissions associated with Portland cement based construction materials. This paper reports on the organic acid resistance of fly ash geopolymers following exposure to acetic and lactic acid. Organic acids are prevalent in many circumstances including agriculture, production processes and waste management. These findings demonstrate that the surface of fly ash geopolymers had superior resistance to organic acids when compared with traditional Portland cement, evidenced by smaller mass losses. This was attributed to the formation of reaction products which were less susceptible to acid attack than those formed in Portland cement systems due to their lower calcium content. However, despite the surface of fly ash geopolymers appearing less deteriorated due to organic acid attack, they were found to have a higher porosity than their Portland cement counterparts making them more susceptible to acid ingress.
\end{abstract}

Keywords Geopolymer · Fly ash · Acetic acid · Lactic acid · Porosity $\cdot$ Corrosion

T. A. Aiken $(\bowtie) \cdot J$. Kwasny · W. Sha

School of Natural and Built Environment, Queen's

University Belfast, Stranmillis Road, Belfast BT9 5AG,

UK

e-mail: taiken02@qub.ac.uk

\section{Introduction}

Organic acids, such as acetic, lactic propionic and butyric acid, can be particularly aggressive to cementitious materials. It is especially significant, as they can often come into contact with agricultural infrastructure and sewage systems [1,2]. Despite organic acids often being described as weak acids compared with strong mineral acids (e.g. sulfuric and hydrochloric acids), the attack on cementitious materials is not necessarily less aggressive. This is due to buffer effects (i.e. slower increase in the $\mathrm{pH}$ of the acid solution for weak acids allowing increased degradation potential) and the high solubility of the organic salts produced following organic acid attack [3-6]. In agriculture, organic acids occur from a range of sources including animal feed [7-9], animal waste [10-12], anaerobic digestion [13, 14] and crop storage [15-18]. When grass is stored as winter feed for livestock, it undergoes a fermentation process converting sugar to acids thus producing silage effluent which contains acetic and lactic acids [17, 19-21]. Figure 1 shows typical damage observed on concrete walls in a silage effluent storage tank. At the average level of silage effluent in the tank, significant damage is visible (Fig. 1b). Large portions of cement paste and mortar have been removed and coarse aggregates have been exposed (Fig. 1c). These concrete walls have been in place for approximately 10 years and are only exposed to silage effluent for a few months per year. Despite this, significant damage has occurred 


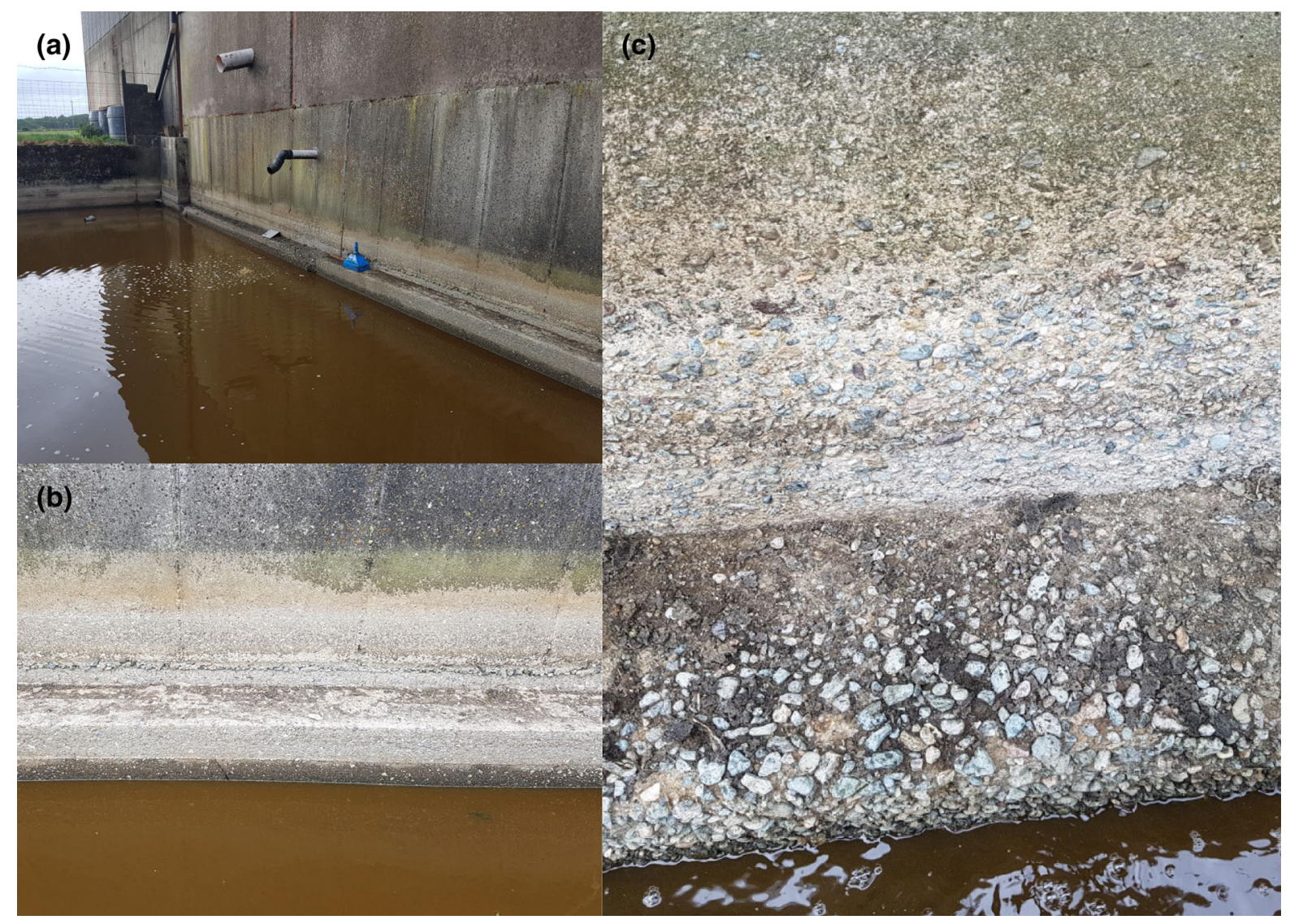

Fig. 1 Photograph of a silage effluent storage tank, b concrete wall showing damage around average effluent level and $\mathbf{c}$ damaged concrete close up

and remedial works are necessary to avoid further breakdown and corrosion of steel reinforcement if the depth of cover for reinforcement has been reduced significantly. Silage effluent also poses a considerable environmental risk. If it leaks into watercourses it can have a detrimental effect on aquatic life due to its high biochemical oxygen demand [22]. Therefore, silage effluent storage facilities need to be watertight to ensure no environmental contamination occurs. Such pollution can incur significant financial penalties alongside the cost of repairing or reconstructing damaged systems which allowed the silage effluent to escape [22].

In sewage systems, biogenic sulfuric acid is typically formed and known to be corrosive to concrete. However, the organic fraction of sewage also commonly contains volatile organic acids such as acetic, propionic and butyric acid [2,23]. The wine, sugar and dairy industries also produce a wide range of organic acids which are corrosive to cementitious materials [24]. Therefore, the organic acid resistance of a relatively new class of fly ash geopolymer binders is of upmost importance in several industries.

Fly ash geopolymers are ceramic-like materials produced by the chemical activation of an aluminosilicate source such as fly ash with alkali to form a hardened binder [25-29]. The most commonly used chemical activators are alkali hydroxide/silicate solutions or a combination of both. The chemical structure of fly ash geopolymers is similar to that of the zeolite except they are amorphous [27]. Geopolymerisation models have been proposed by Fernandez-Jimenez et al. [30] and Duxson et al. [31]. Both models describe dissolution of the aluminosilicate source due to the high $\mathrm{pH}$ of the alkali solutions. This leads to the formation of Si-rich and Al-rich gels, followed by reorganising and polycondensation increasing network connectivity and resulting in the three- 
dimensional aluminosilicate network commonly attributed to geopolymers [30-33].

Fly ash is a residue obtained from coal combustion in coal-fired electricity power stations [34]. On the other hand, the production of traditional Portland cement is an energy intensive process involving the calcination of limestone at high temperatures emitting huge amounts of $\mathrm{CO}_{2}[35,36]$. In fact, the production of 1 tonne of Portland cement emits approximately 0.8 tonnes of $\mathrm{CO}_{2}$, which varies slightly depending on the efficiency of the production facility [37-39].

To date, the majority of research carried out on the acid resistance of fly ash geopolymers has focused on mineral acids such as hydrochloric, sulfuric and nitric acid [40-44]. A previous study by Koenig et al. [1] did study the resistance of a fly ash geopolymer mix to a solution containing various organic acids. The findings demonstrate that exposure to this acid solution resulted in an increased compressive strength and in general good resistance. This performance was attributed to the formation of anorthite in the near surface region of the fly ash geopolymer. Anorthite was formed due to the incorporation of calcium ions in the acid solution. Calcium ions appear to have been present in the acid solution because they leached from other calcium rich binders stored in the same acid solution. As Koenig et al. [1] suggest the incorporation of calcium could be a promising binder specific curing method for fly ash geopolymers. However, in service it is unlikely that organic acid solutions will contain surplus calcium ions to allow the formation of anorthite. Therefore in this study samples from each mix were stored in its own individual container to avoid other samples cross-contamination, i.e. leached ions interacting with other samples and affecting performance. This study focused on the acid resistance of two fly ash geopolymer mortars, with different alkaline activator dosages, when exposed to two organic acids, i.e. acetic and lactic acid. A range of acid concentrations have been considered to ascertain the effect of acid concentration. A comparison of performance has also been carried out with traditional Portland cement mortar. Furthermore, the organic acid resistance of equivalent paste mixes has been studied to gain an understanding of the mechanism of attack on each binder.

\section{Experimental methods}

\subsection{Materials}

Fly ash conforming to BS EN 450-1:2012 [45] was supplied by Power Minerals Ltd., Drax Power Station, North Yorkshire, UK. Portland cement, CEM I 42.5N was supplied by Quinn Cement in Northern Ireland and conformed to BS EN 197-1:2011 [46]. The oxide compositions and loss on ignition (LOI) for both fly ash and Portland cement were obtained by X-ray fluorescence and are shown in Table 1. Previous publications [47, 48] showed the main crystalline phases identified by X-ray diffraction (XRD) present in the fly ash and Portland cement. In the fly ash they are quartz, mullite and hematite, whereas in the Portland cement they are alite, belite, aluminate, brownmillerite and gypsum. The particle size distribution of fly ash, Portland cement and sand are given in Fig. 2.

The activators used were solutions of sodium hydroxide and sodium silicate. The sodium hydroxide solution was prepared at $30 \% \mathrm{w} / \mathrm{w}$ by the dissolution of solid commercial grade ( $99 \%$ purity) sodium hydroxide which was allowed to cool to room temperature prior to sample preparation. Sodium silicate solution containing, $12.8 \% \quad \mathrm{Na}_{2} \mathrm{O}, 25.5 \%$ $\mathrm{SiO}_{2}$ and $61.7 \% \quad \mathrm{H}_{2} \mathrm{O}$ was supplied by Fisher Scientific.

Locally sourced sand, abundant in quartz and also containing albite, muscovite and clinochlore was used

Table 1 Oxide composition and LOI of fly ash and Portland cement

\begin{tabular}{lcc}
\hline Composition (\%) & Fly ash & Portland cement \\
\hline $\mathrm{SiO}_{2}$ & 46.78 & 20.21 \\
$\mathrm{Al}_{2} \mathrm{O}_{3}$ & 22.52 & 4.79 \\
$\mathrm{Fe}_{2} \mathrm{O}_{3}$ & 9.15 & 2.78 \\
$\mathrm{~K}_{2} \mathrm{O}$ & 4.09 & 0.59 \\
$\mathrm{CaO}$ & 2.24 & 63.01 \\
$\mathrm{MgO}$ & 1.33 & 1.93 \\
$\mathrm{TiO}_{2}$ & 1.05 & 0.27 \\
$\mathrm{SO}_{3}$ & 0.90 & 2.60 \\
$\mathrm{Na}_{2} \mathrm{O}$ & 0.89 & 0.19 \\
$\mathrm{MnO}$ & 0.05 & 0.08 \\
$\mathrm{LOI}(\%)$ & 3.57 & 3.16 \\
\hline
\end{tabular}




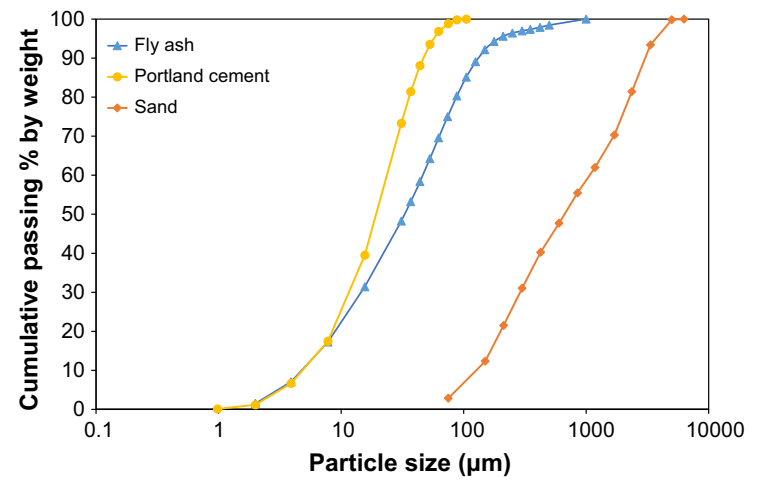

Fig. 2 Particle size distribution of fly ash, Portland cement and sand

as aggregate [49]. The water absorption of the sand was 0.92 and $1.1 \%$ after 1 and $24 \mathrm{~h}$, respectively. The oven dry particle density was $2695 \mathrm{~kg} / \mathrm{m}^{3}$. Both water absorption and density were measured according to BS 812-2:1995 [50]. The sand was dried at $105 \pm 5{ }^{\circ} \mathrm{C}$ for a minimum of $48 \mathrm{~h}$ and allowed to cool to room temperature before mixing. Laboratory grade acetic (99-100\%) and lactic acid ( $\geq 85 \%$ ) were used to prepare $0.10,0.31$ and $0.52 \mathrm{~mol} / \mathrm{L}$ acid solutions for each acid type by mixing in the required proportions with distilled water. Bertron and Duchesne [21] have compiled tables showing the typical concentrations of acetic and lactic acid found in real world scenarios. These typically range between 0.02 and $0.2 \mathrm{~mol} / \mathrm{L}$. Acetic and lactic acids have dissociation constants pKa of 4.76 and 3.86, respectively at $25^{\circ} \mathrm{C}$ [21].

\subsection{Mix proportions}

The mix proportions used are presented in Table 2 . The fly ash geopolymer mixes were based on initial mix design optimisation carried out by Rafeet et al. [51-54] and Vinai et al. [55]. The Portland cement mix proportions were obtained from work carried out by Kwasny et al. [56-58]. The paste content of all mortar mixes was fixed at $50 \%$ and the equivalent pastes were identical, except without the presence of sand. The water/solid ratio was fixed at 0.37 for both fly ash mixes (FA1 and FA2) and the water cement ratio was 0.60 for the Portland cement mix (PC). The absorption water is the amount of water needed to bring the sand to saturated surface dry condition. The total added water is the total amount of water needed plus the absorption water, less the water contained within activating solutions. The 28 day compressive strength of FA1 was $21.5 \mathrm{MPa}$ whereas the compressive strength of FA2 and PC were similar, 55.5 and 53.0 $\mathrm{MPa}$, respectively. FA1 is suitable for low strength applications whereas FA2 and PC are suitable for high strength applications. Alkali dosage and alkali modulus were the parameters used to proportion the quantity of each activating solution used in the geopolymer mixes. The alkali dosage is defined as the percentage of $\mathrm{Na}_{2} \mathrm{O}$ in the binder and the alkali modulus is the ratio of $\mathrm{Na}_{2} \mathrm{O}$ and $\mathrm{SiO}_{2}$ (sometimes referred to as silica modulus). FA1 had an alkali dosage of $7.5 \%$ and an alkali modulus of 1.25 . FA2 had an alkali dosage of $11.5 \%$ and an alkali modulus of 0.95. This resulted in an increased content of both activating solutions in FA2, particularly sodium silicate. These alkali dosages and alkali moduli were chosen based on mix optimisation carried out by Rafeet et al. [51-54] and Vinai et al. [55], aiming for 28-day compressive strength of approximately $20 \mathrm{MPa}$ (FA1) and $50 \mathrm{MPa}$ (FA2 and PC). FA1 had relatively low activator content and is more environmentally friendly than FA2 which had similar compressive strength as that of the PC mix.

\subsection{Sample preparation}

Both mortar and paste samples were prepared with a 101 capacity planar-action high-shear mixer using a similar procedure as that of Kwasny et al. [58]. Firstly, the oven dried sand was placed in the mixing bowl

Table 2 Mix proportions $\left(\mathrm{kg} / \mathrm{m}^{3}\right)$ for geopolymer and Portland cement mortars

\begin{tabular}{llllllrl}
\hline Mix & Fly ash & Portland cement & Sodium silicate & Sodium hydroxide & Absorption water & Total added water & Sand \\
\hline FA1 & 577 & - & 136 & 111 & 12 & 93 & 1348 \\
FA2 & 538 & - & 256 & 126 & 12 & 13 & 1348 \\
PC & - & 544 & - & - & 12 & 326 & 1348 \\
\hline
\end{tabular}


along with half of the total added water and mixed together for $1 \mathrm{~min}$. After $15 \mathrm{~min}$ the powder component (fly ash or Portland cement) of each mix was added. Finally, the remaining water (and activating solutions if appropriate) was added and mixing continued for 6 min before casting.

The samples were cast in two layers into $50 \mathrm{~mm}$ three-gang cubic moulds and each layer was compacted using a vibrating table. After casting the samples were wrapped in cling film to prevent moisture evaporation and placed in the appropriate curing conditions depending on sample type. FA1 and FA2 were cured in a laboratory oven at $70{ }^{\circ} \mathrm{C}$ for 7 days and then placed in the conditioning room at $20 \pm 1{ }^{\circ} \mathrm{C}$ and $50 \pm 5 \%$ relative humidity. PC was cured at $20 \pm 1{ }^{\circ} \mathrm{C}$ and stored on $15 \mathrm{~mm}$ high spacers above $5 \mathrm{~mm}$ of water in sealed containers throughout where the relative humidity was $>90 \%$. Samples were demoulded after $24 \mathrm{~h}$ and returned immediately to the appropriate curing conditions.

\subsection{Testing procedures}

Resistance to organic acid attack was determined using an accelerated method, based on the guidelines provided in ASTM C267 [59] and previous studies [47-49, 60]. The mass loss of $50 \mathrm{~mm}$ mortar cubes following immersion in acid solutions was investigated. After 21 days curing the cubes were placed into a water bath $\left(20 \pm 1{ }^{\circ} \mathrm{C}\right)$ until 28 days when the mass of each cube was recorded. Subsequently sets of four cubes from each were placed into plastic boxes containing acid solutions with concentrations of $0.10,0.31$ and $0.52 \mathrm{~mol} / \mathrm{L}$ of acetic and lactic acid. The acid solution to sample volume ratio was maintained at approximately 0.9 throughout. Every 7 days, visual inspection was carried out, the mass of the mortar cubes was recorded and the acid solution replenished. Additionally the $\mathrm{pH}$ of the acid solution was recorded before replenishment. After 56 days (8 cycles), the average compressive strength was obtained by testing three cubes from each box with a constant loading rate of $50 \mathrm{kN} / \mathrm{min}$. The loading zones were protected with softboard to reduce the effect of uneven surfaces. This method was used instead of capping or grinding to allow immediate testing following acid attack, avoiding testing delays which would have caused issues regarding intermediate sample storage conditions and drying during processing. Control samples which were not exposed to acid were also tested for comparison. The remaining fourth specimen was used to visually inspect the alkalinity loss. This was achieved by splitting the cubes and applying phenolphthalein solution on the split surface which highlights (deep pink/purple) the region where the $\mathrm{pH}$ is greater than approximately 9 [61-63].

Mercury intrusion porosimetry (MIP) was used to assess the pore structure of each mortar mix. At 28 days mortar fragments measuring approximately $8 \times 8 \times 20 \mathrm{~mm}$ were sectioned from the core of each cube using a diamond saw. Hydration/reaction was stopped by oven drying the samples for $24 \mathrm{~h}$ at $60 \pm 1{ }^{\circ} \mathrm{C}$, then immersing them in acetone for $4 \mathrm{~h}$ and subsequently drying them in a desiccator $\left(20 \pm 1{ }^{\circ} \mathrm{C}\right)$ for a further $24 \mathrm{~h}$. The pore structure of the samples was determined using a Pascal 140/240 mercury intrusion porosimeter from ThermoFisher Scientific. The mercury contact angle was taken to be $140^{\circ}$.

Equivalent paste samples were exposed to the same cyclic exposure regime for 21 days ( 3 cycles) for the highest concentration $(0.52 \mathrm{~mol} / \mathrm{L})$ of both acetic and lactic acid. Inductively coupled plasma mass spectroscopy (ICP) was used to analyse the acid solution at the end of each exposure cycle (every 7 days). At the end of 21 days exposure ( 3 cycles), the paste samples were used for microstructural analysis. They were compared with control pastes which were submerged in water instead of acid but otherwise processed in the same way. Powdered samples were obtained by crushing and grinding the outside layer of the paste samples in a pestle and mortar. The powders were dried in a desiccator at $35{ }^{\circ} \mathrm{C}$ for $24 \mathrm{~h}$ prior to analysis. X-ray diffraction (XRD) was carried out with a PANalytical X'Pert PRO diffractometer applying $\mathrm{CuK} \alpha$ radiation of wavelength $1.54 \AA$. Diffraction patterns were collected between 5 and $65^{\circ} 2 \theta$ with a step size of $0.017^{\circ}$. PANalytical X'Pert Highscore software with the powder diffraction file (PDF) database was used to analyse the diffraction patterns. Fourier transform infrared spectroscopy (FTIR) data was obtained using Jasco 4100 series FTIR Spectrometer with attenuated total reflectance attachment. The spectra were gathered between 650 and $2000 \mathrm{~cm}^{-1}$ wavenumber at $8 \mathrm{~cm}^{-1}$ resolution. 


\section{Results and discussion}

The pore structure and porosity results obtained for unexposed mortar samples are discussed first followed by the findings on mass loss, compressive strength loss and alkalinity loss of mortar samples exposed to organic acids. Finally the tests carried out on paste samples are presented including assessment of leaching behaviour ( $\mathrm{pH}$ change of acid solutions due to acid attack of mortars is also monitored) and microstructural changes due to organic acid attack.

\subsection{Porosity and pore structure}

Figure 3 shows the pore size distribution, while Table 3 summarises the pore structure properties obtained by MIP for each mix. It should be noted that Diamond [64] reported that MIP is not always a suitable method for the characterisation of pore size distributions in cementitious materials. This is due to the misallocation of pore sizes related to accessibility and connectivity of the pore network [64] and has been named as the 'ink-bottle' effect [65]. However, Diamond also acknowledged that MIP measurements are useful for comparative purposes of the pore systems in cementitious materials [64], which is the main focus of the MIP measurements reported in this study.

FA1 had a porosity of $19.2 \%$ which was reduced to $16.9 \%$ for FA2 when the alkaline activator dosages were increased. Similarly the average pore diameter was much smaller for FA2 compared with FA1. This was likely to be due to a more complete activation of fly ash in FA2 resulting in a more dense microstructure

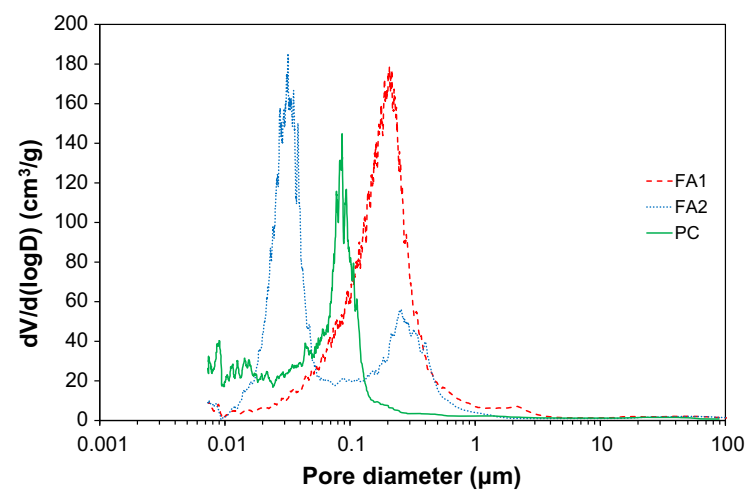

Fig. 3 Differential volume of intruded mercury versus pore diameter for mortar mixes at 28 days
Table 3 Pore structure properties of mortar mixes at 28 days

\begin{tabular}{lccc}
\hline Mix & FA1 & FA2 & PC \\
\hline Porosity $(\%)$ & 19.2 & 16.9 & 12.0 \\
Average pore diameter $(\mu \mathrm{m})$ & 0.111 & 0.043 & 0.034 \\
Total pore surface area $\left(\mathrm{m}^{2} / \mathrm{g}\right)$ & 3.44 & 7.65 & 6.64 \\
\hline
\end{tabular}

$[66,67]$. This can be explained by the nature of fly ash particles and the reaction process as discussed below. Fly ash consists of censospheres which are lightweight spherical particles that can either be hollow or contain smaller spheres called plerospheres [68-71]. The activation process begins with the dissolution of the outside layer of fly ash particles. This uncovers smaller embedded particles which then undergo consecutive dissolution. This results in the inside of larger particles being filled with reaction product, forming a dense matrix [30, 31]. This type of activation process is easily identified in FA2 as shown in Fig. 4. On the other hand, FA1 had a greater number of unreacted spherical fly ash particles (Fig. 4) compared with FA2 due to the lower activator dosages used.

The porosity of the PC mortar (12.0\%) was lower than both FA1 and FA2 (19.2 and 16.9\%) and the average pore diameter of PC $(0.034 \mu \mathrm{m})$ was smaller than both FA1 and FA2 $(0.111$ and $0.043 \mu \mathrm{m})$. This is likely due to the more space filling calcium silicate hydrate $(\mathrm{C}-\mathrm{S}-\mathrm{H})$ formed in Portland cement systems (Fig. 4) compared with the less dense and more porous sodium aluminium silicate hydrate $(\mathrm{N}-\mathrm{A}-\mathrm{S}-\mathrm{H})$ gel formed in fly ash geopolymers [54, 72-75].

\subsection{Mass loss}

Figure 5 shows the mass losses of FA1, FA2 and PC mortar mixes during 56 days exposure to $0.10,0.31$ and $0.52 \mathrm{~mol} / \mathrm{L}$ solutions of acetic and lactic acids. Lactic acid caused increased mass losses compared with acetic acid and is likely due to the lower dissociation constant of lactic acid. Exposure to $0.10 \mathrm{~mol} / \mathrm{L}$ resulted in small mass losses which were negligible for the fly ash geopolymer mixes after 56 days of testing. For PC they were 1.2 and $0.7 \%$ for lactic and acetic acid, respectively, while the mass losses for the both FA1 and FA2 mixes were less than $0.3 \%$ for both acids. Following 56 days exposure to $0.31 \mathrm{~mol} / \mathrm{L}$ of each acid, slightly larger mass losses 

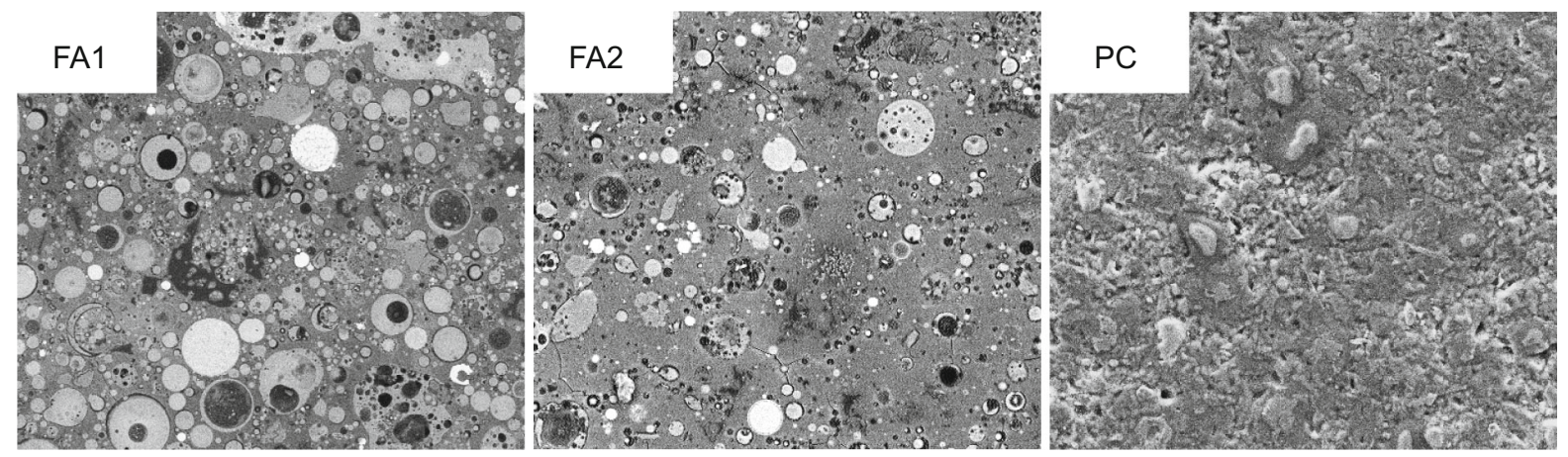

Fig. 4 SEM images of hardened paste samples of FA1, FA2 and PC $(\times 1000)$

were observed, particularly for PC. They had mass losses of 5.5 and $2.8 \%$ for lactic and acetic acid, respectively. The mass losses for the FA1 and FA2 were between 0.5 and $1.2 \%$. Exposure to $0.52 \mathrm{~mol} / \mathrm{L}$ solutions of acetic and lactic acid caused larger mass losses for each mix. PC had a mass loss of $12.9 \%$ due to lactic acid and $5.0 \%$ due to acetic acid. The mass losses for FA1 and FA2 were between 0.8 and $1.8 \%$. Furthermore, the rate of mass loss per cycle appears to be constant or increasing for PC whereas the opposite is true for the FA1 and FA2.

The fly ash geopolymer mixes exhibited relatively similar performance, regardless of the alkaline activator dosages. However, at increased concentrations of lactic acid, FA1 had marginally larger mass losses than FA2. Additionally, the mass losses for FA1 and FA2 are much less than that of PC indicating they are less susceptible to organic acid attack.

Figure 6 shows the visual appearance of FA1, FA2 and PC mortar samples following 56 days exposure to three concentrations of acetic and lactic acids. The fly ash geopolymer mixes appear to become lighter in colour following attack by increased concentrations of both acetic and lactic acid. Apart from the colour change it is difficult to see any signs of surface deterioration. In the case of the PC, there is a visible loss of cement paste from the surface of the samples following exposure to 0.31 and $0.52 \mathrm{~mol} / \mathrm{L}$ solutions. The loss of cement paste also results in the exposure of sand particles causing a rough surface to be observed. More significant cement paste loss is apparent for lactic acid exposure compared with that for acetic acid exposure. These findings are in agreement with the mass losses, i.e. lactic acid causes increased deterioration compared with similar concentrations of acetic acid, particularly for PC.

\subsection{Compressive strength loss}

Figure 7 shows the compressive strength of FA1, FA2 and PC mortar mixes after exposure to 0.10, 0.31 and $0.52 \mathrm{~mol} / \mathrm{L}$ of acetic and lactic acids when tested at the end of the 56 day exposure regime. The compressive strength of samples kept in water (unexposed), tested at the same age as the acid attacked samples is also shown. Exposure to acid, regardless of type or concentration causes a reduction in compressive strength for each mix. Generally as the acid concentration increases the compressive strength loss also increases. Additionally, it appears that lactic acid causes a larger reduction in compressive strength compared with acetic acid. The percentage strength losses demonstrate relatively similar performance for each mix.

\subsection{Alkalinity loss}

Figure 8 shows photographs of the cross sections of FA1, FA2 and PC mortar samples sprayed with phenolphthalein solution. Samples were exposed for 56 days to $0.52 \mathrm{~mol} / \mathrm{L}$ solutions of acetic and lactic acids. Photographs of samples kept in water (unexposed) are included for comparison. The unexposed samples appeared pink/purple across their entire crosssection which indicates that the $\mathrm{pH}$ was above 9.0. It is worth noting that although this shows that the $\mathrm{pH}$ was above 9.0 for each mix, the specific $\mathrm{pH}$ for each mix is not known. There may be some difference in the initial $\mathrm{pH}$ values due to the different composition of each 

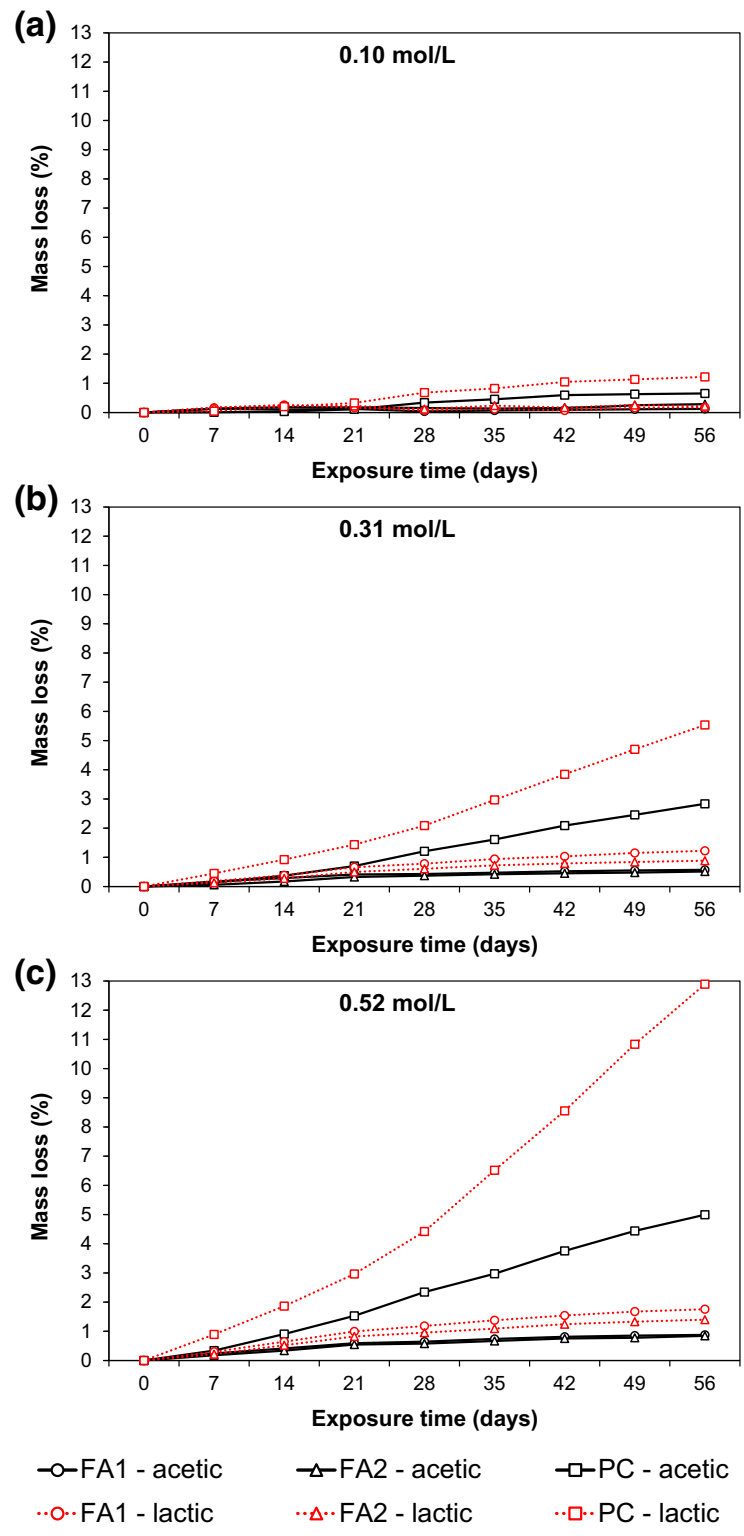

Fig. 5 Mass loss of FA1, FA2 and PC mortar mixes during 56 days exposure to $\mathbf{a} 0.10, \mathbf{b} 0.31$ and $\mathbf{c} 0.52 \mathrm{~mol} / \mathrm{L}$ solutions of acetic and lactic acids

mix. Previous publications from this group [48, 60] showed the evolution of the $\mathrm{pH}$ of water solutions during immersion in water of the equivalent pastes of these mortar mixes. Initially the $\mathrm{pH}$ of the water was 6.8 but increases over time during samples immersion. Eventually the $\mathrm{pH}$ of the water solutions became stable which may provide an indication of the $\mathrm{pH}$ of the pore solution of each mix. We reported that there was only a small difference between each mix, (values ranged between 11.5 and 12.5 following 7 days of immersion) $[48,60]$. This suggests that the difference in the $\mathrm{pH}$ of the pore solution for each mix was small. However, it is expected that the pore solution of FA2 has a slightly higher $\mathrm{pH}$ than FA1 due to the increased alkaline activator dosages. The $\mathrm{pH}$ of the acetic and lactic acid solutions was relatively low $(<3.0)$. Therefore, the effect of the small difference in $\mathrm{pH}$ of each samples pore solution should be almost negligible.

Following 56 days exposure to acetic and lactic acid the $\mathrm{pH}$ of the entire cross-section of FA1 was reduced below 9.0 as no pink/purple region was observed following application of phenolphthalein solution. This suggests that the acid solution had either reached the centre of the sample or caused significant ion exchange throughout the entire sample. In the case of FA2, the central region of the sample appeared pink/purple meaning the $\mathrm{pH}$ remained above 9.0 in this region. This suggests the acid did not ingress or cause significant chemical alteration to the centre of FA2. The superior performance for FA2 was likely related to the reduced porosity of $16.9 \%$, compared with $19.2 \%$ for FA1 (Table 3). The large pores observed in FA1 may also have allowed the acid to ingress rapidly (Fig. 3). This could prove an issue for the use of fly ash geopolymer concrete mixes to protect steel reinforcement from corrosion. The high $\mathrm{pH}$ of concrete is crucial for protecting steel reinforcement from corrosion as it provides a protective layer inhibiting the commencement of corrosion [76].

The performance of PC was vastly different. Almost the entire cross-section of the samples turned pink/purple following the application of phenolphthalein solution. Only the outside layer $(<2 \mathrm{~mm})$ had a reduction in $\mathrm{pH}$ below 9.0. This suggests that the core of PC remained relatively unchanged by the acid. This may be related to the more dense microstructure found in PC (Sect. 3.1). It is worth noting that these results only provide an indication of the depth of acid penetration. However, they do help in understanding the nature of acid attack for each mix. PC suffered much larger mass losses (Fig. 5) and appeared more significantly damaged when samples were visually assessed (Fig. 6). However, the internal core of the samples remained largely unaffected. On the other hand, FA1 and FA2 exhibited smaller mass loss and a relatively undamaged outer surface but their internal 


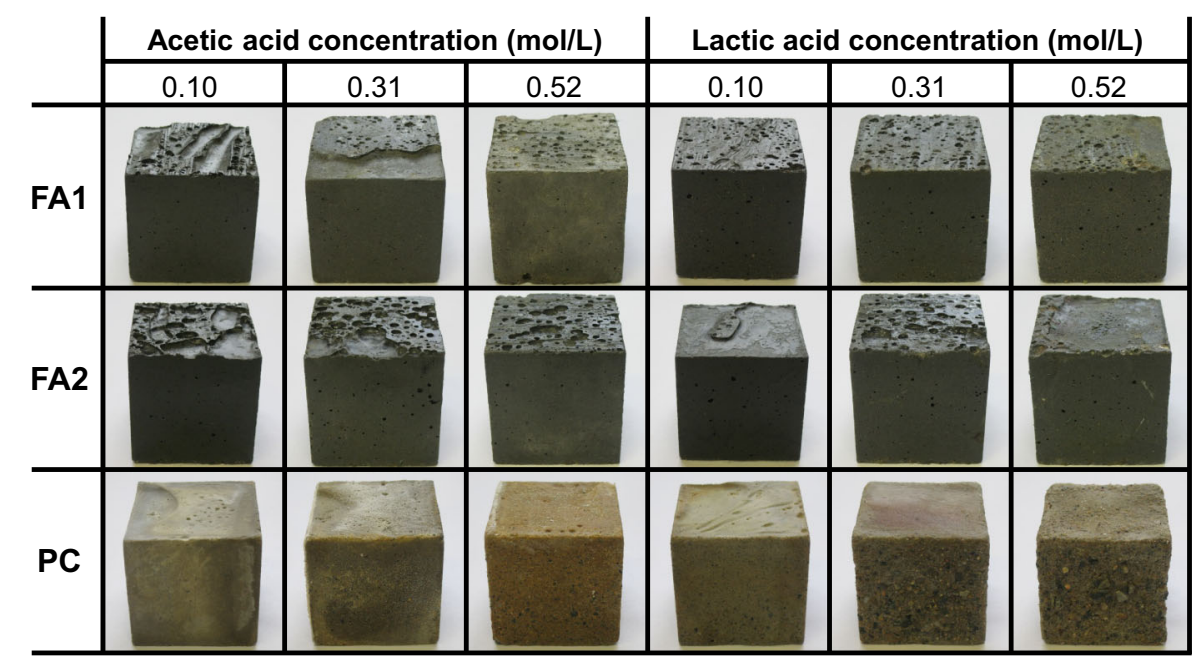

Fig. 6 Visual appearance of FA1, FA2 and PC mortar samples following 56 days exposure to three concentrations of acetic and lactic acids
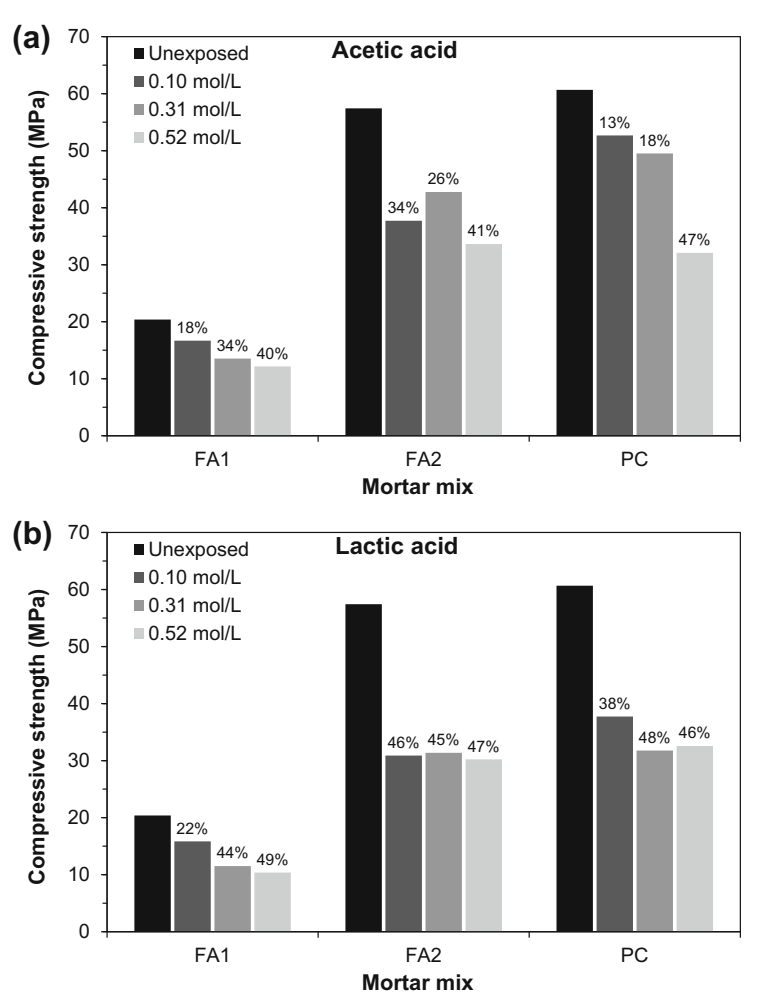

Fig. 7 Compressive strength of FA1, FA2 and PC mortar mixes after 56 days of exposure to $0.10,0.31$ and $0.52 \mathrm{~mol} / \mathrm{L}$ solutions of $\mathbf{a}$ acetic and $\mathbf{b}$ lactic acid. The compressive strength of unexposed samples is also shown. The values above the strength results of samples exposed to acid attack represent the percentage strength loss (i.e. their strength is compared with unexposed samples)

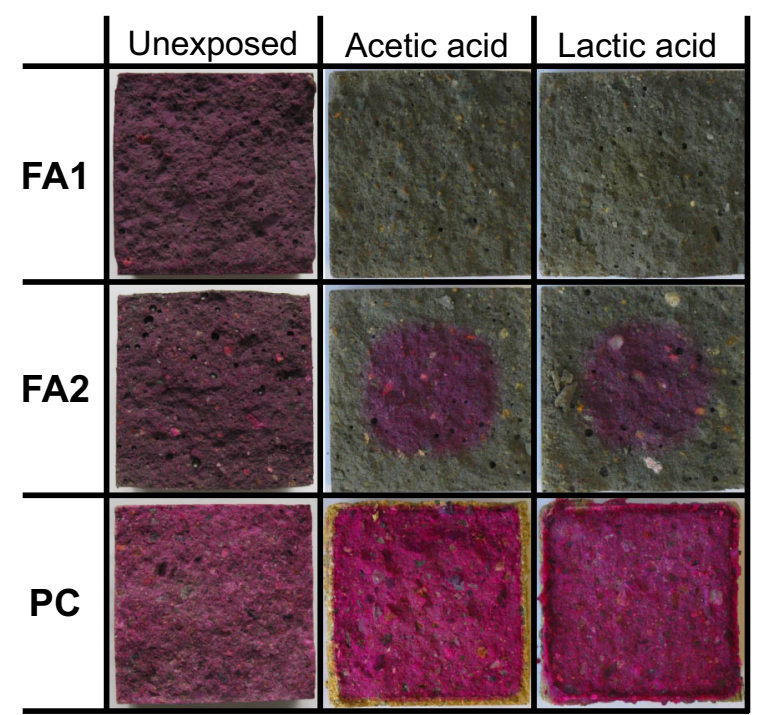

Fig. 8 Photographs of the cross sections of the FA1, FA2 and PC mortar samples sprayed with phenolphthalein solution after exposure to water (unexposed) and $0.52 \mathrm{~mol} / \mathrm{L}$ solutions of acetic and lactic acids

core suffered from a reduction in $\mathrm{pH}$ suggesting greater acid ingress compared with PC.

\subsection{Leaching behaviour}

Figure 9 shows the $\mathrm{pH}$ of the acid solutions at the end of each exposure cycle during exposure of each mortar mix to $0.10,0.31$ and $0.52 \mathrm{~mol} / \mathrm{L}$ solutions of acetic and lactic acids. The $\mathrm{pH}$ of each acid solution is also 
(a)

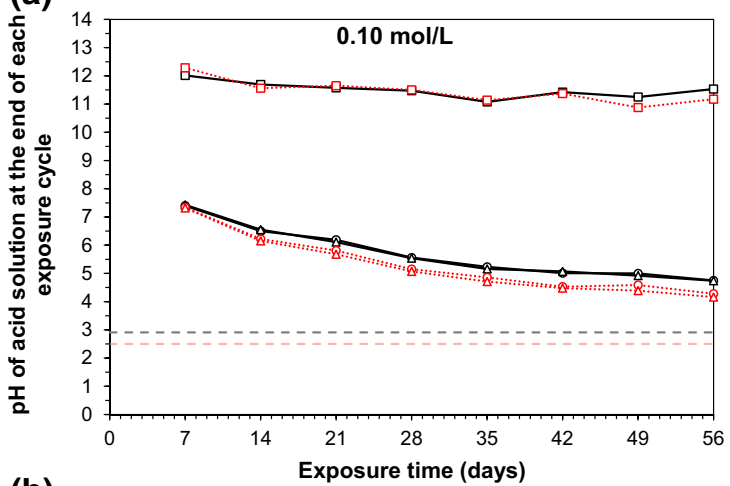

(b)

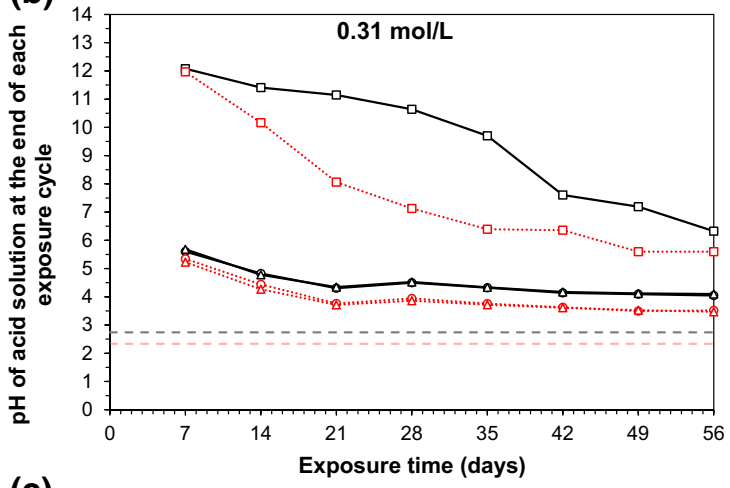

(c)

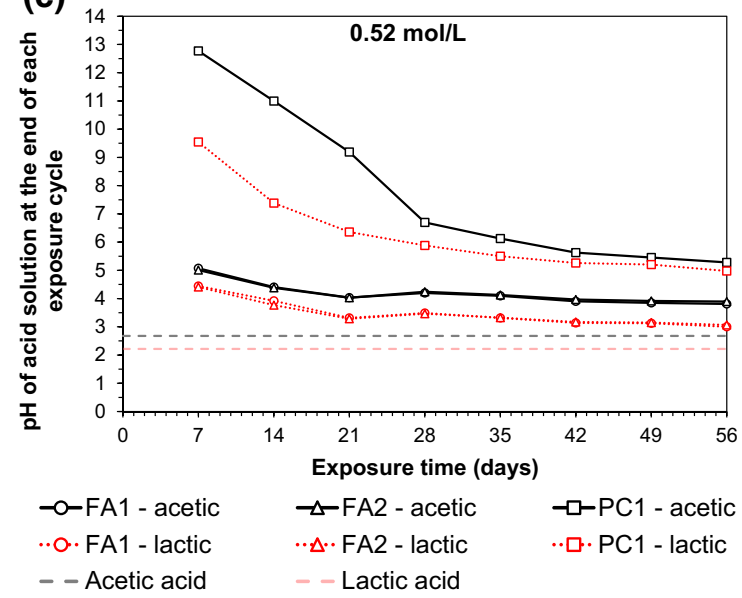

Fig. $9 \mathrm{pH}$ of acid solutions at the end of each exposure cycle during exposure of FA1, FA2 and PC mortars to $\mathbf{a} 0.10, \mathbf{b} 0.31$ and $\mathbf{c} 0.52 \mathrm{~mol} / \mathrm{L}$ of acetic and lactic acid solutions. $\mathrm{pH}$ of original acetic and lactic acid solutions shown by dashed lines

shown as a point of reference. At the end of each exposure cycle the $\mathrm{pH}$ of each acid solution has increased significantly due to the ion exchange between the sample and acid solutions. The $\mathrm{pH}$ increase is much higher for PC throughout which is likely to be due to the availability of calcium which is leached into the acid solution. For both fly ash geopolymer and Portland cement mixes the $\mathrm{pH}$ of the acid solutions used for storing the samples generally decreased with each exposure cycle suggesting fewer ions were available in the samples for exchange. This is likely to be due to depleted (buffer) layers remaining intact preventing heavy leaching to occur from internal layers. For each mix the $\mathrm{pH}$ of the acid solutions was greater for acetic acid compared with lactic acid, this is likely due to the increased initial $\mathrm{pH}$ of the acid solution (Fig. 9). For the PC mix it could also be due to the increased solubility of the calcium salt of acetic acid compared with that of the calcium salt of lactic acid [21], allowing additional $\mathrm{OH}^{-}$anions to go into solution following dissolution of calcium rich phases. This shows the difference in performance of cementitious materials when exposed to different acid types and highlights the value in understanding the performance of materials when exposed to various types of acidic solutions.

Figure 10 shows the cumulative concentration of (a) aluminium, (b) calcium, (c) sodium and (d) silicon in $0.52 \mathrm{~mol} / \mathrm{L}$ acetic and lactic acid solutions during 21 days of paste samples immersion. The main leachate observed from FA1 and FA2 when exposed to both acid types was sodium. This is in agreement with Nguyen and Skvara [77] which found that sodium from fly ash geopolymers naturally diffused slowly into aqueous solutions. Smaller quantities of other elements were also observed including aluminium, calcium, silicon, potassium, magnesium and iron. Concentrations observed were relatively similar for both acid types. However, slightly more aluminium was observed due to lactic acid exposure when compared with acetic acid exposure. This is likely due to lower dissociation constant of lactic acid and the higher solubility of the aluminium salts of lactic acid compared with the aluminium salts of acetic acid [21]. Additionally, the complexation of cations and anions may influence these mechanisms. It has been reported that aluminium complexation by acetate may have an effect on the proportion of aluminium inserted into silica-rich gel formed after acid attack [21, 78, 79]. The increased aluminium found in solution would account for the larger strength losses for FA1 and FA2 due to lactic acid exposure (Fig. 7), and could be related to additional dealumination of $\mathrm{N}-$ A-S-H gel. The main leachate from PC was calcium, with slightly more leached due to acetic acid when 

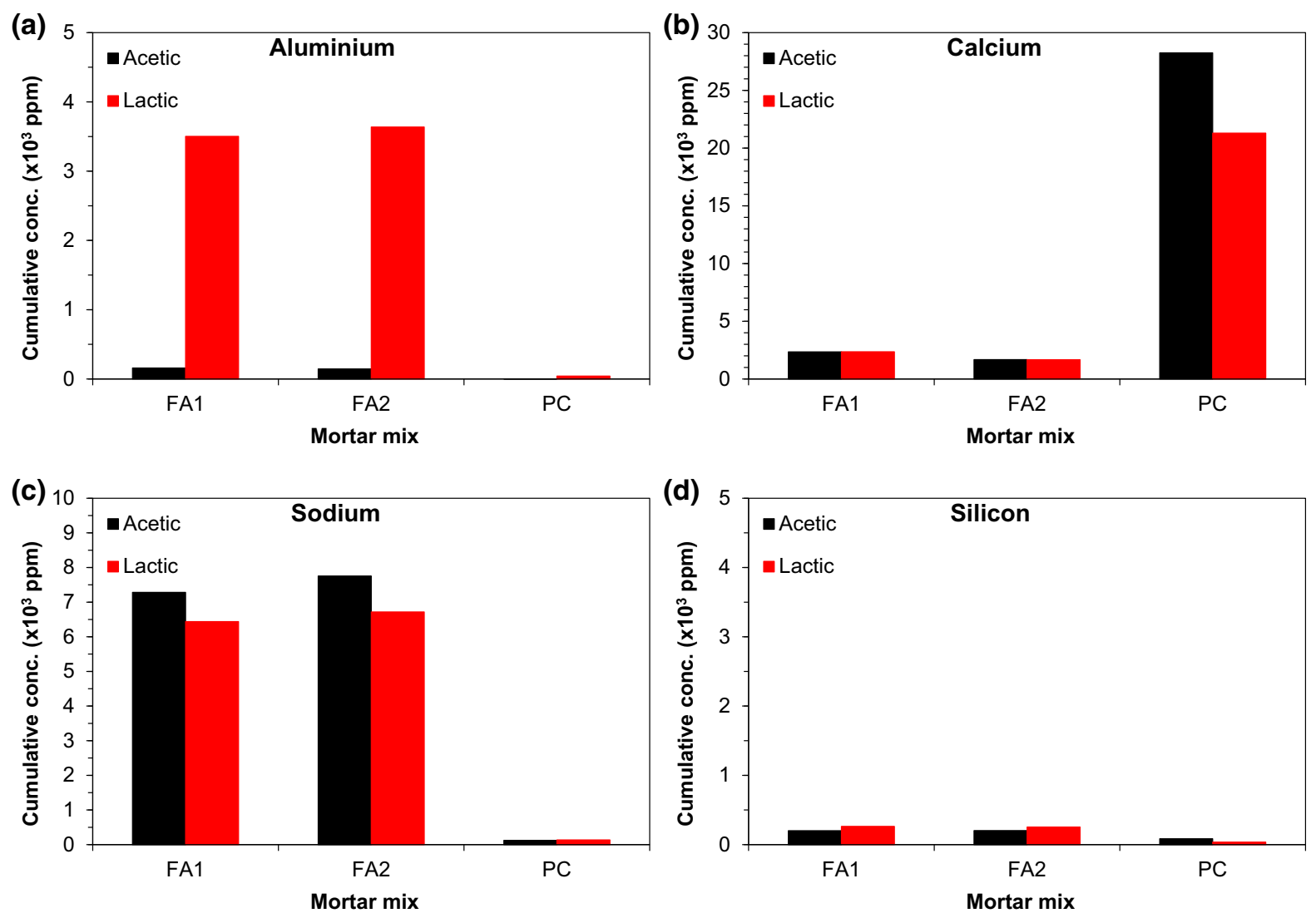

Fig. 10 Cumulative concentration of a aluminium, b calcium, $\mathbf{c}$ sodium and $\mathbf{d}$ silicon in $0.52 \mathrm{~mol} / \mathrm{L}$ acetic and lactic acid solutions following 21 days of FA1, FA2 and PC paste samples immersion

compared with lactic acid. This is likely to be due to the high solubility of calcium acetate which is the calcium salt of acetic acid [78-80].

\subsection{Microstructural changes}

Figure 11 shows the XRD patterns of a) FA1, b) FA2 and c) PC pastes following 21 days of exposure to $0.52 \mathrm{~mol} / \mathrm{L}$ acetic and lactic acid solutions. The fly ash geopolymer and Portland cement pastes which were not exposed to acid are also shown for comparison. The main crystalline phases present in unexposed FA1 and FA2 were quartz $\left(\mathrm{SiO}_{2}\right)$, mullite $\left(\mathrm{Al}_{6} \mathrm{Si}_{2} \mathrm{O}_{13}\right)$ and hematite $\left(\mathrm{FeO}_{2}\right)$. Quartz was identified using PDF \# 01-085-0504 and the main peaks were located at 20.8, 26.6, 50.2 and $60^{\circ} 2 \theta$. Mullite was identified using PDF \# 01-083-1881 and the main peaks were located at $16.4,26.0,26.3,33.2,39.3,40.9,42.6,60.7^{\circ} 2 \theta$. Hematite was identified using PDF \# 01-073-0603 and the main peak was located at $35.6^{\circ} 2 \theta$. The broad hump in FA1 and FA2 between approximately 15 and $30^{\circ} 2 \theta$ indicates the presence of amorphous silicate and aluminosilicate gel phases [75, 81], which in this case was most likely $\mathrm{N}-\mathrm{A}-\mathrm{S}-\mathrm{H}$ gel. Following exposure to both acetic and lactic acids, the peaks due to quartz, mullite and hematite remained and appeared unaffected. The broad hump located between 15 and $30^{\circ} 2 \theta$ was still present which suggests that some form of silicate or aluminosiliacte gel remained following acid exposure. The only change being that the broad hump appeared to shift to be centred at a lower angle. Centring of the peak in this region is typically observed for unreacted fly ash and may suggest that some of the reacted aluminosilicate phases have broken down leaving behind more unreacted fly ash particles [75, 81, 82].

The main crystalline phases identified in PC were calcium hydroxide and ettringite. Calcium hydroxide was identified using PDF \# 01-075-0571 and the main peaks were located at $18.1,34.1,28.7,47.1,50.8,54.4$ 
M-mullite Q-quartz H-hematite E-ettringite $\mathrm{CH}$-calcium hydroxide $\mathrm{C}$-calcite $\mathrm{CL}$-calcium lactate hydrate

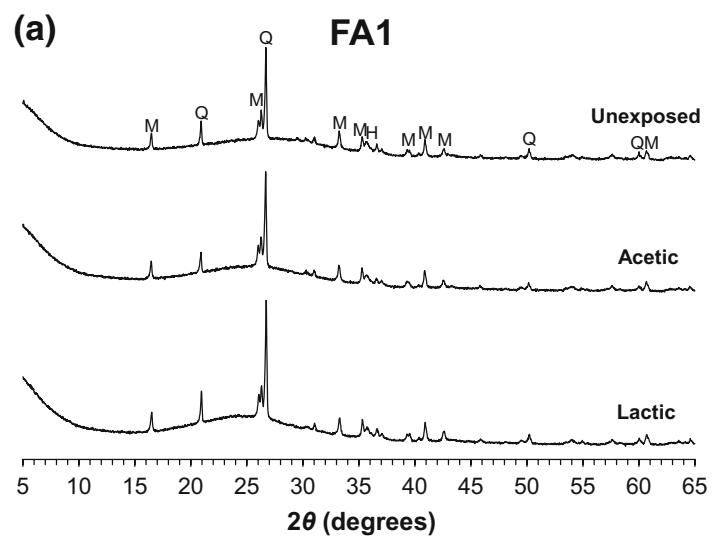

(b)
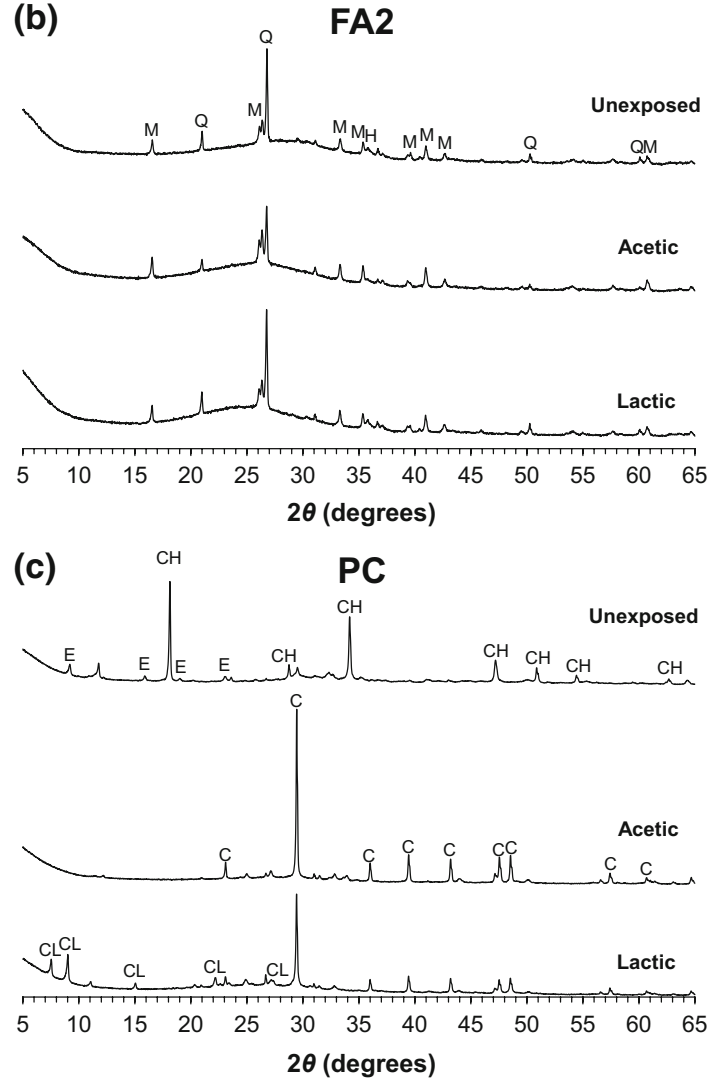

Fig. 11 XRD patterns of a FA1, b FA2 and $\mathbf{c}$ PC pastes stored for 21 days in water (unexposed) and $0.52 \mathrm{~mol} / \mathrm{L}$ acetic and lactic acid solutions

and $62.6^{\circ} 2 \theta$. Ettringite was identified using PDF \# 00-041-1451 and the main peaks were located at 9.1, $15.8,18.9$ and $22.9^{\circ} 20$. Following exposure to both acetic and lactic acids, substantial changes were observed. The peaks associated with calcium hydroxide and ettringite were no longer present indicating they have been removed due to acid attack. Instead calcium carbonate (calcite) was identified by PDF \# 01-086-2334 and the main peaks were located at 23.1, 29.4, 36.0, 39.4, 43.2, 47.5, 48.5, 57.4 and $60.7^{\circ} 2 \theta$. Calcite was also identified by other authors [4, 20, 83] after Portland cement pastes were exposed to acid attack and may be linked to the precipitation of calcium and carbonate ions [10]. Calcium is available from the dissolution of phases with high calcium content such as calcium hydroxide, ettringite and $\mathrm{C}-$ S-H. Carbonate may be present from small amounts of carbon dioxide dissolved in solution [10]. In addition, calcium lactate hydrate was observed following exposure of PC to lactic acid. It was identified by PDF \# 00-005-0101 and the main peaks were located at 7.5, 9.0, 15.0 22.1 and 27.4 20. De Belie et al. [7] and Singh et al. [84] also reported the presence of a salt of calcium lactate due to the interaction between lactic acid and calcium hydroxide. This explains why less calcium was observed due to lactic acid exposure for PC (Fig. 10). The calcium salt of acetic acid was not stable enough to avoid dissolution allowing additional calcium to be observed in the acetic acid solution (Fig. 10).

Figure 12 shows the FTIR spectra of a) FA1, b) FA2 and c) PC paste samples following exposure to $0.52 \mathrm{~mol} / \mathrm{L}$ acetic and lactic acid solutions. The fly ash geopolymer and Portland cement pastes which were not exposed to acid are also shown for comparison. For each sample the small band at approximately $1640 \mathrm{~cm}^{-1}$ was related to vibrations of $\mathrm{OH}$ and $\mathrm{H}-$ $\mathrm{O}-\mathrm{H}$ groups indicting the presence of water molecules [85-88]. For mixes FA1 and FA2, the main peak which was observed at 997 and $991 \mathrm{~cm}^{-1}$, respectively, is assigned to the presence of asymmetrical T$\mathrm{O}$ vibrations $(\mathrm{T}=\mathrm{Si}$ or $\mathrm{Al})$ indicating the presence of $\mathrm{N}-\mathrm{A}-\mathrm{S}-\mathrm{H}$ gel [89]. Following acid attack this main peak shifted to higher wave numbers which indicates a higher $\mathrm{Si} / \mathrm{Al}$ ratio and is attributed to dealumination of the binding gel [90]. The extent of the shift can also be related to the degree of damage caused by acid attack [83]. For FA1 the shift was from 991 to 1022 and $1051 \mathrm{~cm}^{-1}$ for acetic and lactic acid, respectively. For FA2 the shift was from 997 to 1018 and $1049 \mathrm{~cm}^{-1}$ for acetic and lactic acid, respectively. Therefore, the extent of the shift was similar for both FA1 and FA2 suggesting the additional activator dosage in FA2 had 
(a)

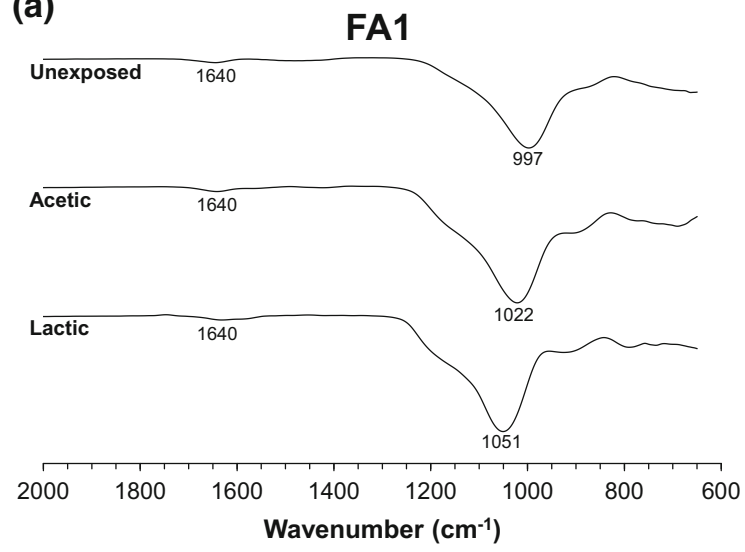

(b)

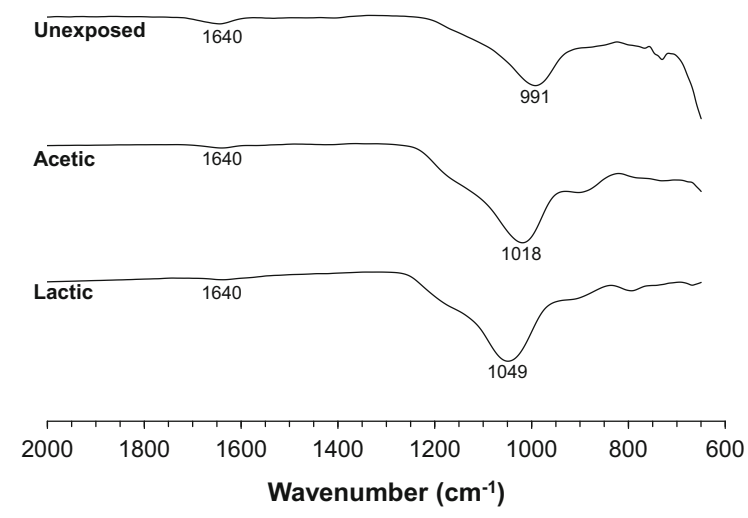

(c)

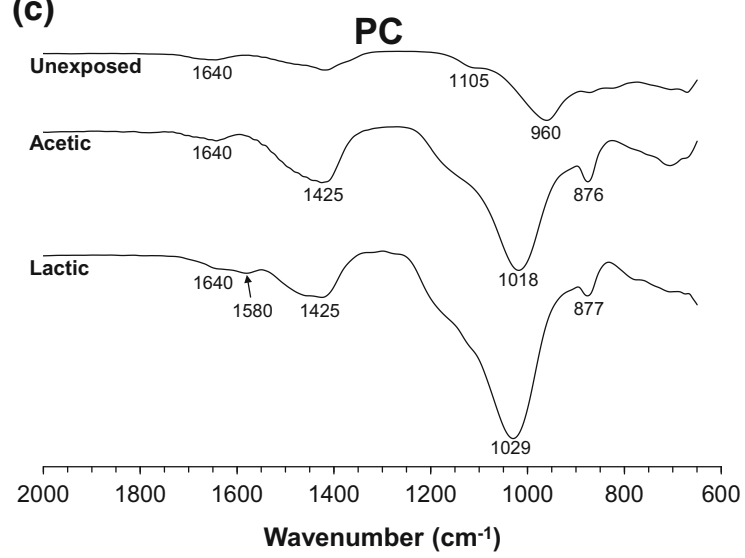

Fig. 12 FTIR spectra of a FA1, b FA2 and c PC pastes stored for 21 days in water (unexposed) and $0.52 \mathrm{~mol} / \mathrm{L}$ acetic and lactic acid solutions

no impact on the resistance of reaction products to acid attack. It can also be noted that the shift was larger for lactic acid for both FA1 and FA2 suggesting lactic acid caused more dealumination. This is in agreement with the leaching behaviour which found increased concentrations of aluminium in the lactic acid solutions (Fig. 10a).

For PC, the main peak was located at $960 \mathrm{~cm}^{-1}$ and shifted to 1018 and $1029 \mathrm{~cm}^{-1}$ for acetic and lactic acid, respectively. This is likely due to the decalcification of C-S-H gel [83], suggesting lactic acid caused further decalcification compared with acetic acid, which is in agreement with the mass losses observed (Fig. 5). PC had a small shoulder at $1105 \mathrm{~cm}^{-1}$ associated with the presence of ettringite [91]. Following acid exposure, this shoulder at $1105 \mathrm{~cm}^{-1}$ was no longer visible suggesting it has been removed due to acid attack. Additional peaks observed at approximately 875 and $1425 \mathrm{~cm}^{-1}$ were due to carbonate species and likely to indicate the presence of calcite [92-94]. At around $1580 \mathrm{~cm}^{-1}$, an additional peak was observed in the PC sample exposed to lactic acid. This peak has previously been related to carboxylic acid salts, in particular calcium lactate hydrate [95-98]. These observations are in agreement with findings from XRD analysis (Fig. 11c).

\section{Conclusions}

This paper investigated the potential of fly ash geopolymers to be used in certain applications where high resistance to organic acid is required. Compared with Portland cement mortar, fly ash geopolymer mortars appeared visibly less susceptible to organic acid attack, i.e. lower degree surface spalling and breakdown of paste was observed. These findings were confirmed by the mass losses, which were significantly larger for the Portland cement mortar. This was due to the enhanced resistance of the reaction products formed. The failure mechanism involved the dealumination of $\mathrm{N}-\mathrm{A}-\mathrm{S}-\mathrm{H}$ gel leaving behind a highly siliceous product. On the other hand, the attack on the surface of Portland cement samples was more aggressive, mainly due to the availability of more phases which are susceptible to organic acid attack. Calcium hydroxide, $\mathrm{C}-\mathrm{S}-\mathrm{H}$ and ettringite were all found to be vulnerable to degradation, mainly due to ion exchange involving calcium. The formation of calcium salts was also a factor. In the case of acetic acid attack, calcium acetate was formed, which is highly soluble and resulted in a high level of calcium being drawn into solution. In the case of lactic acid attack, calcium 
lactate was formed due in part to the dissolution and decalcification of phases such as calcium hydroxide, $\mathrm{C}-\mathrm{S}-\mathrm{H}$ and ettringite. However, despite the reduced mass losses for fly ash geopolymers they have a considerable drawback. Their porosity was relatively higher compared with Portland cement mortars, making them susceptible to loss of alkalinity and ingress of acid, which could be detrimental if used in structures containing steel reinforcement. The percentage strength losses were similar for each mix investigated. Therefore, depending on the indicators considered and end use application, fly ash geopolymer binders may be considered to have better or worse resistance to organic acid than Portland cement binders.

Increasing the alkaline activator dosage had no influence on the resistance of the reaction products formed in fly ash geopolymers, hence similar mass losses were observed. However, a larger compressive strength was obtained and a less porous microstructure was formed, allowing a larger residual strength following acid attack. Additionally, the mix with higher activator dosages (FA2) was less susceptible to alkalinity loss and appeared to prevent to some degree the ingress of acid.

In applications where no structural reinforcement is necessary, fly ash geopolymers have the potential to improve service life due to the resistance of their reaction products. It may be worthwhile to consider fly ash geopolymers as a repair material for surfaces which are experiencing organic acid attack or as a layer of protective material for PC based systems. Although due to the high temperature curing required, attention should be given to develop further applications where some form of high temperature curing is possible, i.e. precast elements. Additionally, consideration should be given to improving the pore structure of fly ash geopolymers making them less susceptible to ingress of acidic solutions. If this can be achieved without affecting the susceptibility of their reaction products to organic acid attack, fly ash geopolymers have the potential to provide enhanced organic acid resistance compared with traditional Portland cement based materials.

Acknowledgements The authors are thankful to the School of Natural and Built Environment, Queen's University Belfast for the facilities provided to conduct this research. The research studentship provided by the Department for the Economy (DfE), Northern Ireland is also gratefully acknowledged. The authors also appreciate the support received and useful discussions had with Prof. Marios Soutsos.

Funding None.

\section{Compliance with ethical standards}

Conflict of interest The authors declare that they have no conflict of interest.

Open Access This article is licensed under a Creative Commons Attribution 4.0 International License, which permits use, sharing, adaptation, distribution and reproduction in any medium or format, as long as you give appropriate credit to the original author(s) and the source, provide a link to the Creative Commons licence, and indicate if changes were made. The images or other third party material in this article are included in the article's Creative Commons licence, unless indicated otherwise in a credit line to the material. If material is not included in the article's Creative Commons licence and your intended use is not permitted by statutory regulation or exceeds the permitted use, you will need to obtain permission directly from the copyright holder. To view a copy of this licence, visit http://creativecommons.org/licenses/by/4.0/.

\section{References}

1. Koenig A, Herrmann A, Overmann S, Dehn F (2017) Resistance of alkali-activated binders to organic acid attack: assessment of evaluation criteria and damage mechanisms. Constr Build Mater 151:405-413. https://doi.org/10.1016/J. CONBUILDMAT.2017.06.117

2. Narkis N, Henefeld-Fourrier S, Rebhun M (1980) Volatile organic acids in raw wastewater and in physico-chemical treatment. Water Res 14:1215-1223. https://doi.org/10. 1016/0043-1354(80)90179-7

3. Koenig A, Dehn F (2016) Main considerations for the determination and evaluation of the acid resistance of cementitious materials. Mater Struct 49:1693-1703. https:// doi.org/10.1617/s11527-015-0605-7

4. Beddoe RE, Dorner HW (2005) Modelling acid attack on concrete: Part I. The essential mechanisms. Cem Concr Res 35:2333-2339. https://doi.org/10.1016/j.cemconres.2005. 04.002

5. Gruyaert E, Van Den Heede P, Maes M, De Belie N (2012) Investigation of the influence of blast-furnace slag on the resistance of concrete against organic acid or sulphate attack by means of accelerated degradation tests. Cem Concr Res 42:173-185. https://doi.org/10.1016/j.cemconres.2011.09. 009

6. Bertron A, Duchesne J, Escadeillas G (2007) Degradation of cement pastes by organic acids. Mater Struct 40:341-354. https://doi.org/10.1617/s11527-006-9110-3

7. De Belie N, Verselder HJ, De Blaere B et al (1996) Influence of the cement type on the resistance of concrete to feed acids. Cem Concr Res 26:1717-1725. https://doi.org/10. 1016/S0008-8846(96)00155-X 
8. De Belie N, Debruyckere M, Van Nieuwenburg D, De Blaere B (1997) Attack of concrete floors in pig houses by feed acids: Influence of fly ash addition and cement-bound surface layers. J Agric Eng Res 68:101-108. https://doi.org/ 10.1006/jaer.1997.0185

9. De Belie N, Monteny J (1998) Resistance of concrete containing styrol acrylic acid ester latex to acids occurring on floors for livestock housing. Cem Concr Res 28:1621-1628. https://doi.org/10.1016/S0008-8846(98)00135-5

10. Bertron A, Escadeillas G, Duchesne J (2004) Cement pastes alteration by liquid manure organic acids: chemical and mineralogical characterization. Cem Concr Res 34:1823-1835. https://doi.org/10.1016/j.cemconres.2004. 01.002

11. Bertron A, Duchesne J, Escadeillas G (2005) Attack of cement pastes exposed to organic acids in manure. Cem Concr Compos 27:898-909. https://doi.org/10.1016/j. cemconcomp.2005.06.003

12. Oueslati O, Duchesne J (2012) The effect of SCMs and curing time on resistance of mortars subjected to organic acids. Cem Concr Res 42:205-214. https://doi.org/10.1016/ j.cemconres.2011.09.017

13. Voegel C, Bertron A, Erable B (2016) Mechanisms of cementitious material deterioration in biogas digester. Sci Total Environ 571:892-901. https://doi.org/10.1016/J. SCITOTENV.2016.07.072

14. Koenig A, Dehn F (2016) Biogenic acid attack on concretes in biogas plants. Biosyst Eng 147:226-237. https://doi.org/ 10.1016/J.BIOSYSTEMSENG.2016.03.007

15. O'Donnell C, Dodd VA, O'Kiely P, Richardson M (1995) A study of the effects of silage effluent on concrete: part 1, significance of concrete characteristics. J Agric Eng Res 60:83-92

16. O'Donnell C, O'Kiely P, Dodd VA, Richardson M (1995) A study of the effects of silage effluent on concrete: part 2, significance of environmental factors. J Agric Eng Res 60:93-97

17. Jones DI, Jones R (1995) The effect of crop characteristics and ensiling methodology on grass silage effluent production. J Agric Eng Res 60:73-81

18. Oueslati O, Duchesne J (2014) Resistance of blended cement pastes subjected to organic acids: quantification of anhydrous and hydrated phases. Cem Concr Compos 45:89-101. https://doi.org/10.1016/J.CEMCONCOMP. 2013.09.007

19. Pavía S, Condren E (2008) A study of the durability of OPC vs. GGBS concrete on exposure to silage effluent. J Mater Civ Eng 20:313-320

20. Bertron A, Duchesne J, Escadeillas G (2005) Accelerated tests of hardened cement pastes alteration by organic acids: analysis of the pH effect. Cem Concr Res 35:155-166. https://doi.org/10.1016/j.cemconres.2004.09.009

21. Bertron A, Duchesne J (2013) Attack of cementitious materials by organic acids in agricultural and agrofood effluents. In: Alexander M, Bertron A, De Belie N (eds) Performance of cement-based materials in aggressive aqueous environments. Springer, Dordrecht, pp 131-173

22. Gebrehanna MM, Gordon RJ, Madani A et al (2014) Silage effluent management: a review. J Environ Manag 143:113-122. https://doi.org/10.1016/j.jenvman.2014.04. 012
23. O'Connell M, McNally C, Richardson MG (2010) Biochemical attack on concrete in wastewater applications: a state of the art review. Cem Concr Compos 32:479-485. https://doi.org/10.1016/j.cemconcomp.2010.05.001

24. Larreur-Cayol S, Bertron A, Escadeillas G (2011) Degradation of cement-based materials by various organic acids in agro-industrial waste-waters. Cem Concr Res 41:882-892. https://doi.org/10.1016/j.cemconres.2011.04.007

25. Davidovits J (2017) Geopolymers: ceramic-like inorganic polymers. J Ceram Sci Technol 8:335-350. https://doi.org/ 10.4416/JCST2017-00038

26. Duxson P, Provis JL, Lukey GC, van Deventer JSJ (2007) The role of inorganic polymer technology in the development of "green concrete". Cem Concr Res 37:1590-1597. https://doi.org/10.1016/j.cemconres.2007.08.018

27. Zhang P, Zheng Y, Wang K, Zhang J (2018) A review on properties of fresh and hardened geopolymer mortar. Compos Part B Eng 152:79-95. https://doi.org/10.1016/J. COMPOSITESB.2018.06.031

28. Sufian Badar M, Kupwade-Patil K, Bernal SA et al (2014) Corrosion of steel bars induced by accelerated carbonation in low and high calcium fly ash geopolymer concretes. Constr Build Mater 61:79-89. https://doi.org/10.1016/J. CONBUILDMAT.2014.03.015

29. Palacios M, Alonso MM, Varga C, Puertas F (2019) Influence of the alkaline solution and temperature on the rheology and reactivity of alkali-activated fly ash pastes. Cem Concr Compos 95:277-284. https://doi.org/10.1016/J. CEMCONCOMP.2018.08.010

30. Fernández-Jiménez A, Palomo A, Criado M (2005) Microstructure development of alkali-activated fly ash cement: a descriptive model. Cem Concr Res 35:1204-1209. https://doi.org/10.1016/j.cemconres.2004. 08.021

31. Duxson P, Fernández-Jiménez A, Provis JL et al (2007) Geopolymer technology: the current state of the art. J Mater Sci 42:2917-2933. https://doi.org/10.1007/s10853-0060637-z

32. Fernández-Jiménez A, Palomo A, Sobrados I, Sanz J (2006) The role played by the reactive alumina content in the alkaline activation of fly ashes. Microporous Mesoporous Mater 91:111-119. https://doi.org/10.1016/j.micromeso. 2005.11.015

33. Palomo A, Alonso S, Fernández-Jiménez A et al (2004) Alkaline activation of fly ashes: NMR study of the reaction products. J Am Ceram Soc 87:1141-1145

34. Pangdaeng S, Phoo-ngernkham T, Sata V, Chindaprasirt P (2014) Influence of curing conditions on properties of high calcium fly ash geopolymer containing Portland cement as additive. Mater Des 53:269-274. https://doi.org/10.1016/j. matdes.2013.07.018

35. Neville AM (2011) Properties of concrete, 5th edn. Pearson Education Limited, Harlow

36. Shen L, Gao T, Zhao J et al (2014) Factory-level measurements on $\mathrm{CO}_{2}$ emission factors of cement production in China. Renew Sustain Energy Rev 34:337-349. https://doi. org/10.1016/j.rser.2014.03.025

37. Feiz R, Ammenberg J, Baas L et al (2015) Improving the $\mathrm{CO}_{2}$ performance of cement, part II: framework for assessing $\mathrm{CO}_{2}$ improvement measures in the cement 
industry. J Clean Prod 98:282-291. https://doi.org/10.1016/ j.jclepro.2014.01.103

38. Ke J, McNeil M, Price L et al (2013) Estimation of $\mathrm{CO}_{2}$ emissions from China's cement production: Methodologies and uncertainties. Energy Policy 57:172-181. https://doi. org/10.1016/j.enpol.2013.01.028

39. Sorrentino F (2011) Chemistry and engineering of the production process: state of the art. Cem Concr Res 41:616-623. https://doi.org/10.1016/j.cemconres.2011.03. 013

40. Fernandez-Jimenez A, García-Lodeiro I, Palomo A (2007) Durability of alkali-activated fly ash cementitious materials. J Mater Sci 42:3055-3065. https://doi.org/10.1007/s10853006-0584-8

41. Thokchom S, Ghosh P, Ghosh S (2009) Resistance of fly ash based geopolymer mortars in sulfuric acid. J Eng Appl Sci 4:65-70

42. Chaudhary D, Liu H (2009) Influence of high temperature and high acidic conditions on geopolymeric composite material for steel pickling tanks. J Mater Sci 44:4472-4481. https://doi.org/10.1007/s10853-009-3678-2

43. Lloyd RR, Provis JL, van Deventer JSJ (2012) Acid resistance of inorganic polymer binders. 1. Corrosion rate. Mater Struct 45:1-14. https://doi.org/10.1617/s11527-011-9744-7

44. Temuujin J, Minjigmaa A, Lee M et al (2011) Characterisation of class $\mathrm{F}$ fly ash geopolymer pastes immersed in acid and alkaline solutions. Cem Concr Compos 33:1086-1091. https://doi.org/10.1016/J.CEMCONCOMP.2011.08.008

45. British Standards Institution (2012) BS EN 450-1:2012-fly ash for concrete. Definition, specifications and conformity criteria. London

46. British Standards Institution (2011) BS EN 197-1:2011 cement part 1: composition, specifications and conformity criteria for common cements. London

47. Aiken TA, Sha W, Kwasny J, Soutsos MN (2017) Resistance of geopolymer and Portland cement based systems to silage effluent attack. Cem Concr Res 92:56-65. https://doi. org/10.1016/j.cemconres.2016.11.015

48. Aiken TA, Kwasny J, Sha W, Soutsos MN (2018) Effect of slag content and activator dosage on the resistance of fly ash geopolymer binders to sulfuric acid attack. Cem Concr Res 111:23-40. https://doi.org/10.1016/j.cemconres.2018.06. 011

49. Kwasny J, Aiken TA, Soutsos MN et al (2018) Sulfate and acid resistance of lithomarge-based geopolymer mortars. Constr Build Mater 166:537-553. https://doi.org/10.1016/j. conbuildmat.2018.01.129

50. British Standards Institution (1995) BS 812-2:1995 testing aggregates. Methods for determination of density. Springer, London

51. Rafeet A, Vinai R, Sha W, Soutsos M (2014) Alkali activated fuel ash and slag mixes: optimization study from mortars to concrete building blocks. In: Proceedings of 34th cement and concrete science conference and workshop on waste cementation. Sheffield, pp 349-353

52. Rafeet A (2016) Mix design, fresh and hardened properties and microstructural characterization of alkali-activated concrete based on PFA/GGBS blends. Queen's University Belfast, PhD thesis

53. Rafeet A, Vinai R, Soutsos M, Sha W (2017) Guidelines for mix proportioning of fly ash/GGBS based alkali activated concretes. Constr Build Mater 147:130-142. https://doi.org/ 10.1016/j.conbuildmat.2017.04.036

54. Rafeet A, Vinai R, Soutsos M, Sha W (2019) Effects of slag substitution on physical and mechanical properties of fly ash-based alkali activated binders (AABs). Cem Concr Res 122:118-135. https://doi.org/10.1016/J.CEMCONRES. 2019.05.003

55. Vinai R, Rafeet A, Soutsos M, Sha W (2016) The role of water content and paste proportion on physico-mechanical properties of alkali activated fly ash-ggbs concrete. J Sustain Metall 2:51-61. https://doi.org/10.1007/s40831-0150032-6

56. Kwasny J, Soutsos MN, McIntosh JA, Cleland DJ (2016) banahCEM-comparison of properties of a laterite-based geopolymer with conventional concrete. In: Jones MR, Newlands MD, Halliday JE, et al (eds) Proceedings of 9th international concrete conference: environment, efficiency and economic challenges for concrete. Dundee, pp 383-394

57. Kwasny J, Aiken TA, Soutsos MN et al (2018) Comparison of lithomarge and cement-based mortars performance in aggressive aqueous environments. In: International conference on the durability of concrete structures. Leeds

58. Kwasny J, Soutsos MN, McIntosh JA, Cleland DJ (2018) Comparison of the effect of mix proportion parameters on behaviour of geopolymer and Portland cement mortars. Constr Build Mater 187:635-651. https://doi.org/10.1016/J. CONBUILDMAT.2018.07.165

59. American Society for Testing and Materials (2012) ASTM C267-01(2012) Standard test methods for chemcial resistance of mortars, grouts, and monolithic surfacings and polymer concretes

60. Aiken TA (2017) Durability of geopolymer materials in aggressive aqueous environments-acid attack, steel reinforcement corrosion and freeze-thaw attack. Queen's University Belfast, $\mathrm{PhD}$ thesis

61. Chang C-F, Chen J-W (2006) The experimental investigation of concrete carbonation depth. Cem Concr Res 36:1760-1767. https://doi.org/10.1016/j.cemconres.2004. 07.025

62. Liu E, Ghandehari M, Brückner C et al (2017) Mapping high $\mathrm{pH}$ levels in hydrated calcium silicates. Cem Concr Res 95:232-239. https://doi.org/10.1016/j.cemconres.2017.02. 001

63. Chinchón-Payá S, Andrade C, Chinchón S (2016) Indicator of carbonation front in concrete as substitute to phenolphthalein. Cem Concr Res 82:87-91. https://doi.org/10.1016/j. cemconres.2015.12.010

64. Diamond S (2000) Mercury porosimetry: an inappropriate method for the measurement of pore size distributions in cement-based materials. Cem Concr Res 30:1517-1525. https://doi.org/10.1016/S0008-8846(00)00370-7

65. Lloyd RR, Provis JL, Smeaton KJ, van Deventer JSJ (2009) Spatial distribution of pores in fly ash-based inorganic polymer gels visualised by Wood's metal intrusion. Microporous Mesoporous Mater 126:32-39. https://doi.org/ 10.1016/j.micromeso.2009.05.016

66. Chi M (2015) Effects of modulus ratio and dosage of alkaliactivated solution on the properties and micro-structural characteristics of alkali-activated fly ash mortars. Constr Build Mater 99:128-136. https://doi.org/10.1016/j. conbuildmat.2015.09.029 
67. Sindhunata J, Van Deventer SJ, Lukey GC, Xu H (2006) Effect of curing temperature and silicate concentration on fly-ash-based geopolymerization. Ind Eng Chem Res 45:3559-3568. https://doi.org/10.1021/ie051251p

68. Wesche K (1991) Fly ash in concrete. Chapman \& Hall, London

69. Malhotra VM, Kumar Mehta P (1996) Pozzolanic and cementitious materials. Taylor \& Francis, Abingdon

70. Kolay PK, Singh DN (2001) Physical, chemical, mineralogical, and thermal properties of cenospheres from an ash lagoon. Cem Concr Res 31:539-542. https://doi.org/10. 1016/S0008-8846(01)00457-4

71. Oh JE, Jun Y, Jeong Y (2014) Characterization of geopolymers from compositionally and physically different Class F fly ashes. Cem Concr Compos 50:16-26. https://doi. org/10.1016/J.CEMCONCOMP.2013.10.019

72. Lothenbach B, Scrivener K, Hooton RD (2011) Supplementary cementitious materials. Cem Concr Res 41:1244-1256. https://doi.org/10.1016/j.cemconres.2010. 12.001

73. Noushini A, Castel A (2016) The effect of heat-curing on transport properties of low-calcium fly ash-based geopolymer concrete. Constr Build Mater 112:464-477. https://doi. org/10.1016/j.conbuildmat.2016.02.210

74. Provis JL, Myers RJ, White CE et al (2012) X-ray microtomography shows pore structure and tortuosity in alkaliactivated binders. Cem Concr Res 42:855-864. https://doi. org/10.1016/j.cemconres.2012.03.004

75. Bernal SA, Provis JL, Walkley B et al (2013) Gel nanostructure in alkali-activated binders based on slag and fly ash, and effects of accelerated carbonation. Cem Concr Res 53:127-144. https://doi.org/10.1016/j.cemconres.2013.06. 007

76. Thiery M, Villain G, Dangla P, Platret G (2007) Investigation of the carbonation front shape on cementitious materials: Effects of the chemical kinetics. Cem Concr Res 37:1047-1058. https://doi.org/10.1016/j.cemconres.2007. 04.002

77. Nguyen AD, Škvára F (2016) The influence of ambient pH on fly ash-based geopolymer. Cem Concr Compos 72:275-283. https://doi.org/10.1016/J.CEMCONCOMP. 2016.06.010

78. De Windt L, Devillers P (2010) Modeling the degradation of Portland cement pastes by biogenic organic acids. Cem Concr Res 40:1165-1174. https://doi.org/10.1016/j. cemconres.2010.03.005

79. De Windt L, Bertron A, Larreur-Cayol S, Escadeillas G (2015) Interactions between hydrated cement paste and organic acids: thermodynamic data and speciation modeling. Cem Concr Res 69:25-36. https://doi.org/10.1016/j. cemconres.2014.12.001

80. Gutberlet T, Hilbig H, Beddoe RE (2015) Acid attack on hydrated cement - effect of mineral acids on the degradation process. Cem Concr Res 74:35-43. https://doi.org/10. 1016/J.CEMCONRES.2015.03.011

81. Shearer CR, Provis JL, Bernal SA, Kurtis KE (2016) Alkaliactivation potential of biomass-coal co-fired fly ash. Cem Concr Compos 73:62-74. https://doi.org/10.1016/j. cemconcomp.2016.06.014

82. Provis JL, Lukey GC, van Deventer JSJ (2005) Do geopolymers actually contain nanocrystalline zeolites? A reexamination of existing results. Chem Mater 17:3075-3085. https://doi.org/10.1021/cm050230i

83. Bernal SA, Rodríguez ED, de Gutierrez RM, Provis JL (2012) Performance of alkali-activated slag mortars exposed to acids. J Sustain Cem Mater 1:37-41. https://doi. org/10.1080/21650373.2012.747235

84. Singh NB, Prabha S, Singh AK (1986) Effect of lactic acid on the hydration of portland cement. Cem Concr Res 16:545-553. https://doi.org/10.1016/0008-8846(86)90092$\mathrm{X}$

85. Palomo A, Blanco-Varela MT, Granizo ML et al (1999) Chemical stability of cementitious materials based on metakaolin. Cem Concr Res 29:997-1004. https://doi.org/ 10.1016/S0008-8846(99)00074-5

86. Gao XX, Michaud P, Joussein E, Rossignol S (2013) Behavior of metakaolin-based potassium geopolymers in acidic solutions. J Non Cryst Solids 380:95-102. https://doi. org/10.1016/j.jnoncrysol.2013.09.002

87. Gao X, Yu QL, Brouwers HJH (2015) Reaction kinetics, gel character and strength of ambient temperature cured alkali activated slag-fly ash blends. Constr Build Mater 80:105-115. https://doi.org/10.1016/j.conbuildmat.2015. 01.065

88. Puertas F, Fernández-Jiménez A (2003) Mineralogical and microstructural characterisation of alkali-activated fly ash/ slag pastes. Cem Concr Compos 25:287-292

89. García-Lodeiro I, Fernández-Jiménez A, Blanco MT, Palomo A (2008) FTIR study of the sol-gel synthesis of cementitious gels: C-S-H and N-A-S-H. J Sol-Gel Sci Technol 45:63-72. https://doi.org/10.1007/s10971-0071643-6

90. Bascarevic Z, Komljenovic M, Miladinovic Z et al (2013) Effects of the concentrated $\mathrm{NH}_{4} \mathrm{NO}_{3}$ solution on mechanical properties and structure of the fly ash based geopolymers. Constr Build Mater 41:570-579. https://doi.org/10.1016/j. conbuildmat.2012.12.067

91. Perkins RB, Palmer CD (1999) Solubility of ettringite $\left(\mathrm{Ca}_{6}\left[\mathrm{Al}(\mathrm{OH})_{6}\right]_{2}\left(\mathrm{SO}_{4}\right)_{3} 26 \mathrm{H}_{2} \mathrm{O}\right)$ at $5-75{ }^{\circ} \mathrm{C}$. Geochim Cosmochim Acta 63:1969-1980. https://doi.org/10.1016/ S0016-7037(99)00078-2

92. Lecomte I, Henrist C, Ligeois M et al (2006) (Micro)structural comparison between geopolymers, alkali-activated slag cement and Portland cement. J Eur Ceram Soc 26:3789-3797. https://doi.org/10.1016/j.jeurceramsoc. 2005.12.021

93. Mollah MYA, Lu F, Cocke DL (1998) An X-ray diffraction (XRD) and Fourier transform infrared spectroscopic (FTIR) characterization of the speciation of arsenic (V) in Portland cement type-V. Sci Total Environ 224:57-68. https://doi.org/10.1016/S0048-9697(98)00318-0

94. Yu P, Kirkpatrick RJ, Poe B et al (2004) Structure of calcium silicate hydrate (C-S-H): near-, mid-, and far-infrared spectroscopy. J Am Ceram Soc 82:742-748. https://doi.org/ 10.1111/j.1151-2916.1999.tb01826.x

95. National Institute of Standards and Technology (2018) Calcium lactate. In: NIST Chem. Webbook, SRD69. https:// webbook.nist.gov/cgi/cbook.cgi?ID=C5743475\&Mask= 80\#IR-Spec. Accessed 22 Apr 2020

96. Tian S, Hou Y, Wu W et al (2015) Reversible absorption of $\mathrm{SO}_{2}$ from simulated flue gas by aqueous calcium lactate 
solution. J Taiwan Inst Chem Eng 54:71-75. https://doi.org/ 10.1016/j.jtice.2015.03.026

97. Song X, Wang H, Yang X et al (2014) Hydrolysis of poly(lactic acid) into calcium lactate using ionic liquid [Bmim] [OAc] for chemical recycling. Polym Degrad Stab 110:65-70. https://doi.org/10.1016/j.polymdegradstab. 2014.08.020

98. Sedlarik V, Saha N, Kuritka I et al (2006) Modification of poly(vinyl alcohol) with lactose and calcium lactate: potential filler from dairy industry. Plast Rubber Compos 35:355-359. https://doi.org/10.1179/174328906X149682

Publisher's Note Springer Nature remains neutral with regard to jurisdictional claims in published maps and institutional affiliations. 